\title{
The Azospirillum genus and the cultivation of vegetables. A review
}

\author{
Eduardo Pradi Vendruscolo ${ }^{(1)}$, Sebastião Ferreira de Lima ${ }^{(2)}$
}

\author{
(1) Mato Grosso do Sul State University. Cassilândia University Unit. MS 306 Rd., km 6.4. 79540-000 Cassilândia, Mato \\ Grosso do Sul (Brazil).E-mail: agrovendruscolo@gmail.com \\ (2) Federal University of Mato Grosso do Sul. Chapadão do Sul Campus. MS 306 Rd., km 105. 79560-000 Chapadão do Sul, \\ Mato Grosso do Sul (Brazil).
}

Received 8 February 2021, accepted 24 September 2021, available online 21 October 2021.

This article is distributed under the terms and conditions of the CC-BY License (http://creativecommons.org/licenses/by/4.0)

Introduction. Plant growth-promoting rhizobacteria have been successfully inserted in agriculture, aiming to find a better balance between agricultural production and environmental protection. However, there is a restriction on its application concerning the exploited species since the focus is on large-scale grain production, practically excluding small and mediumsized farms.

Literature. Studies on the application of Azospirillum bacteria in horticultural species are still scarce, compared with those aimed at grain production. However, it appears that these bacteria are beneficial to the development and production of vegetables, whether they produce leaves, stems, bulbs, flowers, fruits, roots, or tubers, and may result in monetary gains, especially for small and medium agricultural producers.

Conclusions. The use of Azospirillum bacteria to increase the quality and quantity of products from horticultural species and establish an environmentally friendly practice is a reality. However, the development of research that defines the best strategies for using this technology must be carried out continuously, aiming at the best conditions for producers.

Keywords. Nitrogen fixation, agricultural sustainability, plant-bacteria interaction, environmentally friendly products, plant protection, beneficial organism.

\section{Le genre Azospirillum et la culture des légumes (synthèse bibliographique)}

Introduction. Des rhizobactéries favorisant la croissance des plantes ont été insérées avec succès dans l'agriculture, dans le but de rechercher un meilleur équilibre entre la production agricole et la protection de l'environnement. Cependant, il y a une restriction à son application en ce qui concerne les espèces exploitées, car l'accent est mis sur la production céréalière à grande échelle, excluant pratiquement les petites et moyennes exploitations.

Littérature. Les études sur l'application de la bactérie Azospirillum dans les espèces horticoles sont encore naissantes, comparées à celles visant la production céréalière. Cependant, il apparait que ces bactéries sont bénéfiques au développement et à la production d'une série de légumes, qu'elles produisent des feuilles, des tiges, des bulbes, des fleurs, des fruits, des racines ou des tubercules, et peuvent entrainer des gains monétaires, en particulier pour les petits et moyens producteurs.

Conclusions. L'utilisation de la bactérie Azospirillum pour augmenter la qualité et la quantité de produits issus d'espèces horticoles, en plus d'établir une pratique respectueuse de l'environnement, est une réalité. Cependant, le développement de la recherche qui définit les meilleures stratégies d'utilisation de cette technologie doit être mené en continu, en visant les meilleures conditions pour les producteurs ruraux.

Mots-clés. Fixation de l'azote, durabilité agricole, interaction plante-bactérie, produits respectueux de l'environnement, protection des plantes, organisme bénéfique.

\section{INTRODUCTION}

Plant growth-promoting rhizobacteria have been the constant focus of research to reduce production costs, increase yield, and promote plant and environmental protection by reducing the supply of chemical fertilizers. These assumptions have been confirmed by countless studies developed over the past decades, most of them focused on grain production, mainly of grass species (Fukami et al., 2018; Leite et al., 2019).

The success achieved by using Azospirillum in grasses allowed the study area to expand, encompassing other crops of commercial interest from different botanical families, such as soybeans (Silva et al., 2019), beans (Filipini et al., 2020), sunflower (Komy et al., 2020), among others. Also, the focus was 
on crops produced on a large scale, with positive or often indifferent results, demonstrating a relationship between the species used, both plant and bacteria.

The Azospirillum genus is widespread in the agricultural scenario, mainly due to the recognized ability to fix atmospheric nitrogen in higher plants (Cassán et al., 2020). However, the effects of interactivity between plants and bacteria go further (Fukami et al., 2018). These bacteria also affect plant development through hormonal changes, or even providing resistance to weather conditions through the set of effects (Cássan \& Diaz-Zorita, 2016; Sahu et al., 2017; Silva et al., 2019), in addition to enabling the activation of different structural, biochemical and molecular mechanisms (Guerrero-Molina et al., 2014).

The diverse positive interactions between bacteria and plant species arouse the interest of all productive sectors, such as the production of vegetables. One of the main characteristics of this sector is the great diversity of cultivated species, making it essential to carry out specific studies, thus avoiding generalization regarding the use of plant growth-promoting rhizobacteria. Also, the studies contribute to an efficient introduction of new technologies available on the market, helping small, medium, and large vegetable producers.

This review aims to compile results and discussions about the use of bacteria of the Azospirillum genus in vegetables, focusing on their applicability and impact on the productive sector.

\section{METHODOLOGY}

The main terms related to the topic were listed in search of current and relevant information about the use of bacteria of the Azospirillum genus in horticultural species. Each of the following terms was used in individual or combined consultations: (“Azospirillum" OR "diazotrophic bacteria" OR "nitrogen fixing bacteria" OR "biological nitrogen fixation" OR "PGPR" OR "phytostimulation" OR "symbiosis" OR "rhizobacteria") AND ("horticulture" OR "vegetable species" OR "leaf vegetables" OR "vegetables" OR "fruits" OR "fruit vegetables" OR "tubers" OR "root vegetables" OR "symbiosis"). Also, in conjunction with the terms, the genus and common names of the main species representing each botanical family and the names of the families were used, including Asteraceae $\{$ Lactuca (lettuce)\}; Allioideae $\{$ Allium (onion and garlic) $\}$, Brassicaceae \{Eruca (arugula) and Brassica (cabbage, broccoli, and cabbage)\}, Solanaceae \{Solanum (tomato and potato), Capsicum (pepper)\}, cucurbits \{Cucumis (cucumber and melon), Cucurbita (pumpkin)\}, legumes \{Vicia (string beans), Cicer (chickpeas), Pisium (peas) and Lens (lentils)\}, Asparagus (asparagus), Fragaria (strawberry), Manihot (cassava), Cynara (artichoke) and Abelmoschus (okra).

During the research, 78 scientific papers were listed (92.4\% with up to 10 years and $7.6 \%$ with more than 10 years of publication, until 2021), which were selected according to the relevance to the topic addressed in the research. Among the studies, we selected those that reported the use of bacteria of the Azospirillum genus in horticultural species, which may contain results obtained in the field or controlled environments. For this, searches were concentrated on the following platforms: Scopus ${ }^{\circledR}$ (Elsevier), PubMed ${ }^{\circledR}$, Google Scholar ${ }^{\circledR}$, Scielo®, and Portal de Periódicos Capes ${ }^{\circledR}$.

\section{STEMS, LEAVES, AND BULBS}

The Azospirillum genus falls within the group of plant growth-promoting rhizobacteria (PGPRs) (Kloepper \& Schroth, 1978). Although it has stood out for a longer time in use in species from the Poaceae family, it started to interest the horticultural sector for the possible benefits provided, such as reduced use of nitrogen (Lima et al., 2017; Aguirre et al., 2018), increased yield (Aponte et al., 2017) and product quality, among others. Still, it highlights the interest in producing organic vegetables as a good option for crop management.

In the group of vegetables that produce stems, leaves, and bulbs, there are still few scientific studies found with the use of Azospirillum, especially lettuce and onion, within the leafy and bulb-producing areas (Table 1), respectively. For plants that have the stem as a commercial interest, it was observed in agricultural cultivation of asparagus (Asparagus officinalis L.), the presence of a great diversity of nitrogen-fixing bacteria associated with plants (López et al., 1998), and Altamirano et al. (2020) obtained from all isolated material, the presence of $50 \%$ of bacteria of the Azospirillum genus.

Lettuce has a fast production cycle, making the initial establishment important in defining its yield capacity. In this sense, greater germination of lettuce seeds was verified when inoculated with Azospirillum sp. (Barassi et al., 2006). However, more research is needed to define the effects of Azospirillum at this stage of the crop, considering that controversial results are also verified. Romagna et al. (2019) evaluated the effect of the A.brasilense application on lettuce seeds and seedlings, finding a reduction in germination, shoot size, and dry matter accumulation.

Working with lettuce in tropical conditions, Aponte et al. (2017) found that the association of Azospirillum with Pseudomonas fluorescens promoted greater seedling emergence, greater leaf area, and greater dry mass, highlighting the advantages of the bio- 
Table 1. Effect of Azospirillum inoculation on vegetables that produce leaves and bulbs - Effet de l'inoculation d'Azospirillum sur les légumes qui produisent des feuilles et des bulbes.

\begin{tabular}{|c|c|c|c|}
\hline Azospirillum species & Vegetable species & Effect & Reference \\
\hline Azospirillum sp. & \multirow{7}{*}{$\begin{array}{l}\text { Lettuce } \\
\text { (Lactuca sativa L.) }\end{array}$} & + germination rates & Barassi et al., 2006 \\
\hline $\begin{array}{l}\text { Azospirillum } \mathrm{sp} .+ \\
\text { Pseudomonas fluorescens }\end{array}$ & & $\begin{array}{l}+ \text { seedling emergence, }+ \text { leaf area } \\
\text { and dry mass }\end{array}$ & Aponte et al., 2017 \\
\hline A. rugosum & & + growth,+ nutrient uptake & Lai et al., 2008 \\
\hline \multirow[t]{4}{*}{ A. brasilense } & & $\begin{array}{l}+ \text { tolerance to viruses },+ \text { fresh weight } \\
\text { production }\end{array}$ & Lima et al., 2017 \\
\hline & & $\begin{array}{l}\text { - germination, - shoot size and dry } \\
\text { matter }\end{array}$ & Romagna et al., 2019 \\
\hline & & $\begin{array}{l}+ \text { salt tolerance, }+ \text { growth rate, } \\
+ \text { chlorophyll content, }+ \text { ascorbic } \\
\text { acid content, }+ \text { antioxidant capacity, } \\
+ \text { storage time, }+ \text { visual quality }\end{array}$ & Fasciglione et al., 2015 \\
\hline & & + IAA & Mangmang et al., 2015b \\
\hline Azospirillum sp. & Onion (Allium сера L.) & Inexistent & Romero et al., 2016 \\
\hline
\end{tabular}

consortium of strains. According to the same authors, these microorganisms act synergistically and can trigger a tolerance mechanism for lettuce under abiotic stress conditions.

Studying the association of doses of swine manure and A.rugosum in lettuce, Lai et al. (2008) found that plants were benefited in growth, mass production, and accumulation of nutrients as the levels of manure increased, indicating a potentiation in the association with the use of swine manure. It was also verified by Lima et al. (2017) that A. brasilense provides greater tolerance of lettuce to viruses of the Tospovirus group and reduces the effects of larvae-miner when associated with the use of rooting in lower doses of $\mathrm{N}$ in topdressing.

Greater production of total fresh lettuce mass was obtained with the use of Azospirillum associated with increasing $\mathrm{N}$ doses, possibly due to the optimization of the use of N (Lima et al., 2017), due to its ability to promote greater root development of plants (Lade et al., 2018; Pérez-Rodriguez et al., 2020).

For the situation of salt stress in the cultivation of lettuce, it was observed that inoculation with Azospirillum promoted greater production of fresh biomass, chlorophyll, and ascorbic acid content, improving the general visual quality and the antioxidant capacity, allowing to extend the storage time of the lettuce (Fasciglione et al., 2015).

The use of different strains of Azospirillum has proved to be promising for the main crops, including some vegetables. The use of the Azospirillum 7A strain on lettuce was efficient in increasing the plant height, shoot dry matter, and chlorophyll content. However, it did not differ from the foliar application of bee honey at a concentration of $2 \%$ (Romero et al., 2016). It was also observed that the Sp245 strain of A.brasilense was efficient in increasing the level of Indole-3-acetic acid (IAA) in lettuce plants (Mangmang et al., 2015b).

It should be noted that IAA is present in all plants and has the most important role in their growth and development, allowing cell stretching and division, tissue differentiation, phototropism, gravitropism, and defensive responses (Leveau \& Lindow, 2005). The amino acid tryptophan, which higher plants, such as lettuce, exude, constitutes the precursor to microbial IAA biosynthesis (Idris et al., 2007).

For the chives (Allium fistulosum L.), it was found that the use of raw and composted chicken manure has a negative effect on Azospirillum sp., possibly due to the presence of copper $(\mathrm{Cu})$, which is toxic to the microorganism (Montenegro-Gómez et al., 2017). This fact is important because olericulture uses manure extensively. In the case of chives, it may lose the benefits generated by applying Azospirillum or native strains present in the soil.

For the cultivation of onion (Allium cepa L.), Romero et al. (2016), working with two strains of Azospirillum (7A and AMRp10), showed no effect on plant height, stem diameter, bulb diameter, leaf area, and dry mass of the plant, while the chlorophyll index was impaired with the use of these strains.

\section{FLOWERS AND FRUITS}

There is a great lack of information about using plant growth-promoting rhizobacteria in species with commercial value in their flowers or inflorescences. In this sense, for the Brassica oleracea L. var. italica, it was verified that in addition to the isolated effect of 
inoculation with Azospirillum, there is also a positive interaction of the bacteria and the application of mineral nitrogen. In this condition, there was a greater accumulation of nutrients in the aerial part of the plants and a consequent increase in the development of plant organs and yield (Abou El-Magb et al., 2014). The same authors also highlight the role of Azospirillum in promoting phytohormone levels (GA3, IAA, and cytokinin), with a direct effect on cell division and stretching (Table 2).

The promotion of growth due to the presence in higher concentrations of phytohormones was also related to the gains obtained with the artichoke (Cynara scolymus L.) (Eldeen et al., 2015). In this study, the combined use of bacteria and mineral nitrogen promoted significant gains in vegetative development, yield, and quality of the flowers produced.

Different from that found for inflorescence type vegetables, a considerable number of studies aimed at applying Azospirillum in fruit-producing vegetables. In this sense, it appears that species of the botanical family Solanaceae, mainly varieties of Lycopersicon esculentum Mill., have responded positively to the inoculation with bacteria, not only concerning the gains in development but also in terms of increased resistance as to biotic and abiotic factors (CortésJiménez et al., 2014; Romero et al., 2014; Fujita et al., 2017).

For tomato, it is verified that the inoculation of plants with A.brasilense improves the physiological activities of photosynthesis, accumulation of pigments, and antioxidant compounds (Lade et al., 2018; PérezRodriguez et al., 2020). These changes increase vegetative development, yield (Escalante et al., 2015; Esquivel-Cote etal.,2017; Lima etal.,2018), and quality of the fruits (Caradonia et al., 2020). Many results are related to the higher production of phytohormones, emphasizing abscisic acid, atmospheric $\mathrm{N}$ fixation, and P solubilization (Mangmang et al., 2015b; Pereg et al., 2016; Dudás et al., 2017).

In a study based on the inoculation of Capsicum annuum L. plants with A. brasilense, Aguirre-Medina \& Moreno (2016) found a significant increase in vegetative development. However, these increments did not increase fruit yield or its size. A similar result was obtained with plants of Capsicum chinense Jacq., where inoculation with A.brasilense did not result in significant gains in developing the plant and fruits (Reyes-Ramírez et al., 2014). In contrast, the inoculation of Capsicum annuum var. aviculare with A.halopraeferens provided increases in vegetative development of the plants and their composition related to the protein content in these organs during the flowering period, but with no effect on the yield or bromatological traits of the seeds (Hernández et al., 2018).
Among cucurbits, it appears that the inoculation of cucumber plants (Cucumis sativus L.) with different strains of $A$. brasilense results in greater germination vigor and development of aerial and root organs, partly due to the higher concentration of endogenous IAA (Mangmang et al., 2015a). In addition, these changes improve the ability of plants to establish in the field since the root system is stimulated to develop by the presence of phytohormones (Mangmang et al., 2016).

In abiotic stress situations, such as in soils with toxic levels of $\mathrm{Cu}$, the inoculation of cucumber plants with A.brasilense helped in partially mitigating the deleterious effects, allowing the plants to grow significantly better (Marastoni et al., 2019). The best plant conditions, the ability of bacteria to fix atmospheric $\mathrm{N}$ and solubilize $\mathrm{P}$, culminate in yield gains, increasing the number of female flowers produced and the size and quality of cucumber fruits (El Sayed et al., 2015).

Other species of cucurbits also respond to inoculation with Azospirillum (Kumar et al., 2018). In this sense, inoculation resulted in higher germination and initial development rate and increased yield and fruit quality of Cucurbita pepo L., with an additive effect to mineral fertilization (Zarei et al., 2015).

Unlike what was observed for the other cucurbits, the inoculation of melon plants (Cucumis melo L.) with A. brasilense did not affect the vegetative development of the plants, nor did the relative levels of leaves chlorophyll, a fact related to the initial management of fertilization tanned cattle manure, which enabled better conditions for plant development (Vendruscolo et al., 2019). However, the authors found a positive effect of inoculation on fruit size and yield traits in this same study. Yield gains were also observed by Vendruscolo et al. (2020), who associated the effects of inoculation with $A$. brasilense to the greater economic return with melon.

Several studies reported responsiveness for strawberry plants (Fragaria $\times$ ananassa Duch.) submitted to inoculation with Azospirillum. In these, it is observed that, in addition to the stimulus for vegetative development, due to the greater accumulation of nutrients in the tissues and greater production of phytohormones involved in the expansion of organs and cellular activity (Guerrero-Molina et al., 2014; Elías et al., 2018; Andrade et al., 2019), there is a considerable increase in fruit yield and quality (Salazar et al., 2012; Kumar et al., 2019). Such results are also related to activating different structural, biochemical, and molecular mechanisms, resulting in plants being more resistant to damage caused by stressful events (Guerrero-Molina et al., 2014).

It is also noteworthy that besides the isolated effect, it was found that inoculation with $A$. brasilense was also effective when increasing doses of nitrogen were used, which characterizes an additive effect of inoculation in 
Table 2. Effect of Azospirillum inoculation on vegetables that produce flowers and fruits - Effet de l'inoculation d'Azospirillum sur les légumes qui produisent des fleurs et des fruits.

\begin{tabular}{|c|c|c|c|}
\hline Azospirillum species & Vegetable species & Effect & References \\
\hline A.brasilense & $\begin{array}{l}\text { Broccoli } \\
\text { (Brassica oleracea } \text { L. var. itálica) }\end{array}$ & $\begin{array}{l}\text { + nutrient uptake, + growth, } \\
\text { + yield }\end{array}$ & $\begin{array}{l}\text { Abou El-Magb et al., } \\
2014\end{array}$ \\
\hline A. lipoferum & $\begin{array}{l}\text { Artichoke } \\
\text { (Cynara scolymus L.) }\end{array}$ & $\begin{array}{l}\text { + nutrient uptake, + growth, } \\
+ \text { yield }\end{array}$ & Eldeen et al., 2015 \\
\hline \multirow[t]{7}{*}{ A.brasilense } & \multirow[t]{7}{*}{$\begin{array}{l}\text { Tomato } \\
\text { (Lycopersicon esculentum Mill.) }\end{array}$} & + salt tolerance & $\begin{array}{l}\text { Cortés-Jiménez et al., } \\
\text { 2014; Escalante et al., } \\
2015\end{array}$ \\
\hline & & + water deficit tolerance & Romero et al., 2014 \\
\hline & & $\begin{array}{l}\text { + photosynthesis },+ \text { pigments, } \\
+ \text { antioxidant compounds }\end{array}$ & Lade et al., 2018 \\
\hline & & + growth,+ yield & Lima et al., 2018 \\
\hline & & + fruit quality & Caradonia et al., 2020 \\
\hline & & + yield,+ fruit quality & $\begin{array}{l}\text { Pérez-Rodriguez et al., } \\
2020\end{array}$ \\
\hline & & + growth,+ yield & $\begin{array}{l}\text { Esquivel-Cote et al., } \\
2017\end{array}$ \\
\hline Azospirillum sp. & & + disease tolerance & Fujita et al., 2017 \\
\hline \multirow[t]{2}{*}{ A. brasilense } & $\begin{array}{l}\text { Sweet pepper } \\
\text { (Capsicum annuиm L.) }\end{array}$ & + growth,$=$ yield & $\begin{array}{l}\text { Aguirre-Medina \& } \\
\text { Moreno, } 2016\end{array}$ \\
\hline & Pepper (Capsicum chinense Jacq.) & & $\begin{array}{l}\text { Reyes-Ramírez et al., } \\
2014\end{array}$ \\
\hline A. halopraeferens & $\begin{array}{l}\text { Pepper } \\
\text { (Capsicum annuum var. aviculare) }\end{array}$ & $\begin{array}{l}\text { + growth, + protein content, } \\
\text { = yield, = fruit quality }\end{array}$ & Hernández et al., 2018 \\
\hline \multirow[t]{10}{*}{ A.brasilense } & \multirow[t]{4}{*}{$\begin{array}{l}\text { Cucumber } \\
\text { (Cucumis sativus L.) }\end{array}$} & $\begin{array}{l}\text { + germination vigor, + growth, } \\
+ \text { IAA content }\end{array}$ & Mangmang et al., 2015a \\
\hline & & $\begin{array}{l}+ \text { growth, + IAA content } \\
+ \text { phosphorus uptake }\end{array}$ & Mangmang et al., 2016 \\
\hline & & $\begin{array}{l}\text { + female flowers, + yield },+ \text { fruit } \\
\text { quality }\end{array}$ & El Sayed et al., 2015 \\
\hline & & + growth,+ toxic $\mathrm{Cu}$ mitigation & Marastoni et al., 2019 \\
\hline & \multirow{2}{*}{$\begin{array}{l}\text { Melon } \\
\text { (Cucumis melo L.) }\end{array}$} & $=$ growth,+ yield & Vendruscolo et al., 2019 \\
\hline & & + yield,+ economic returns & Vendruscolo et al., 2020 \\
\hline & \multirow[t]{4}{*}{$\begin{array}{l}\text { Strawberry } \\
(\text { Fragaria } \times \text { ananassa } \text { Duch.) }\end{array}$} & $\begin{array}{l}+ \text { GA content, + molecular } \\
\text { responses, - lipid peroxidation }\end{array}$ & $\begin{array}{l}\text { Guerrero-Molina et al., } \\
2014\end{array}$ \\
\hline & & $\begin{array}{l}\text { + growth, + ethylene content, } \\
+ \text { molecular responses }\end{array}$ & Elías et al., 2018 \\
\hline & & + growth,+ IAA content & Andrade et al., 2019 \\
\hline & & + yield,+ fruit quality & $\begin{array}{l}\text { Salazar et al., 2012; } \\
\text { Kumar et al., } 2019\end{array}$ \\
\hline \multirow[t]{2}{*}{ Azospirillum sp. } & \multirow[t]{2}{*}{$\begin{array}{l}\text { Okra } \\
\text { (Abelmoschus esculentus L.) }\end{array}$} & $\begin{array}{l}+ \text { growth },+ \text { pigments },+ \text { proteins, } \\
+ \text { glucose },+ \text { ascorbic acid },+ \text { free } \\
\text { amino acids, }+ \text { nitrate reductase } \\
\text { activity }\end{array}$ & $\begin{array}{l}\text { Baliah et al., 2015; } \\
\text { Baliah \& Muthulakshmi, } \\
2017\end{array}$ \\
\hline & & + yield, + fruit quality & Sharma et al., 2014 \\
\hline
\end{tabular}


Table 2 (continued). Effect of Azospirillum inoculation on vegetables that produce flowers and fruits - Effet de l'inoculation d'Azospirillum sur les légumes qui produisent des fleurs et des fruits.

\begin{tabular}{|c|c|c|c|}
\hline Azospirillum species & Vegetable species & Effect & References \\
\hline A. lipoferum & $\begin{array}{l}\text { Chickpea } \\
\text { (Cicer arietinum L.) }\end{array}$ & $\begin{array}{l}\text { + growth, + pigments, }+ \text { proteins, } \\
+ \text { sugars },+ \text { nutrient uptake, } \\
+ \text { molecular responses, } \\
+ \text { antioxidant activity }\end{array}$ & El-Esawi et al., 2019 \\
\hline Azospirillum sp. & $\begin{array}{l}\text { Pea } \\
\text { (Pisum sativum L.) }\end{array}$ & $\begin{array}{l}+ \text { antioxidant activity, }+ \text { growth } \\
+ \text { pigments },+ \text { yield }\end{array}$ & Ejaz et al., 2020 \\
\hline \multirow[t]{2}{*}{ A.brasilense } & Faba bean (Vicia faba L.) & + chlorophyll content & Kholdi et al., 2015 \\
\hline & Lentil (Lens culinaris Medik.) & + growth,+ yield & Darabi et al., 2014 \\
\hline
\end{tabular}

strawberry cultivation (Reddy \& Goyal, 2021). In this study, a positive effect of the inoculation of seedlings with A.brasilense on the vegetative and reproductive traits was verified, in addition to the increase in the quality of the fruits from inoculated plants, which had significant increases in the levels of soluble solids and anthocyanins. In contrast, there was a reduction in the acidity of the fruits.

The vegetative traits and tissue composition of okra (Abelmoschus esculentus [L.] Moench) were also altered by inoculating the plants with Azospirillum. There was a significant increase in germination, followed by greater development of branches, roots, leaves, and accumulation of dry mass, in addition to increased levels of chlorophyll, proteins, glucose, carotenoids, ascorbic acid, free amino acids, and nitrate reductase activity (Baliah et al., 2015; Baliah \& Muthulakshmi, 2017). It is interesting to highlight that in the study by Baliah et al. (2015), the vehicles for applying the bacteria were also evaluated, which have a determining influence on the effectiveness of the inoculation, even though all treatments composed by Azospirillum have been beneficial to the crop.

Okra fruit yield and size were also favored by inoculation of okra seeds with Azospirillum (Sharma et al., 2014). The authors relate the results to the biological fixation of atmospheric $\mathrm{N}$ to the solubilization of phosphate and the increase in the levels of phytohormones and nutrients in the vegetative organs, which result in an adequate function of the physiological mechanisms and consequent improvement of the yield traits. Also, the study points to a significant economic gain when there is the inoculation of the okra seeds with the bacteria.

The mitigation of abiotic stress effects has been the focus of many studies related to the application of bacteria of the Azospirillum genus in leguminous plants, such as Cicer arietinum L., Vicia faba L., and Pisum sativum L. (Kholdi et al., 2015; El-Esawi et al., 2019; Ejaz et al., 2020). This protection is related to changes leveraged by inoculation with bacteria, resulting in activation of defense genes, production of antioxidant agents, and increase in photosynthetic activity, among other traits that help maintain vital activities of plants, even under adverse conditions of development.

The same factors that give leguminous species less susceptibility to environmental factors also help obtain greater vegetative development and higher yield and quality of harvested products. Fact observed regarding the traits of Lens culinaris Medik., under different shading conditions (Darabi et al., 2014), P. sativum, under different regimes of $\mathrm{N}$ and $\mathrm{P}$ (Ejaz et al., 2020), and $V$. faba under conditions of combined inoculation and the application of humic acid (Kholdi et al., 2015). Also, the use of co-inoculation of Azospirillum and other bacteria that promote plant development in legumes is highlighted, which has been considered an effective tool for producing these species (Cassán et al., 2020).

\section{ROOTS AND TUBERS}

The role of bacteria of the Azospirillum genus as promoters of root development, through stimuli related to the increase of endogenous levels of phytohormones, accumulation of reserves, promotion of photosynthesis, and absorption of nutrients (Mangmang et al., 2016; Lade et al., 2018; Pérez-Rodriguez et al., 2020) justifies its exploitation in crops producing roots and tubers (Table 3). Also, the induction to mitigate the effects of environmental factors, such as water scarcity and toxicity due to the presence of elements such as aluminium (Cássan \& Diaz-Zorita, 2016; Sahu et al., 2017; Silva et al., 2019). This vegetable production sector is a factor of interest due to the characteristics of the areas explored with crops of great interest, such as cassava (Paz et al., 2020).

Naturally, bacteria promoting biological $\mathrm{N}$ fixation, including bacteria of the Azospirillum genus, are associated with cassava plants (Manihot esculenta Crantz) (Leite et al., 2018) makes it possible to make inferences to a predisposition of the species for inoculation. In this sense, inoculation with 
Table 3.Effect of Azospirillum inoculation on vegetables that produce roots and tubers - Effet de l'inoculation d'Azospirillum sur les légumes qui produisent des racines et des tubercules.

\begin{tabular}{|c|c|c|c|}
\hline Azospirillum species & Vegetable species & Effect & References \\
\hline & \multirow{4}{*}{$\begin{array}{l}\text { Cassava } \\
\text { (Manihot esuculenta } \text { Crantz) }\end{array}$} & + growth & Lopes et al., 2019 \\
\hline Azospirillum spp. & & + starch quality & $\begin{array}{l}\text { Hernández-Fernández et al., } \\
2016\end{array}$ \\
\hline A. brasilense & & + vitamin $C,=$ growth,$=$ yield & Sharara \& El-Aal, 2016 \\
\hline Azospirillum sp. & & $\begin{array}{l}\text { + yield, + nutrient uptake, } \\
+ \text { disease protection }\end{array}$ & Hridya \& Byju, 2014 \\
\hline Azospirillum sp. & $\begin{array}{l}\text { Sweet potatoes } \\
\text { (Ipomoea potatoes) }\end{array}$ & + yield,+ root quality & Nedunchezhiyan et al., 2010 \\
\hline A. lipoferum & & + yield, + P solubilization & $\begin{array}{l}\text { Pérez-Pazos \& Sánchez- } \\
\text { López, } 2018\end{array}$ \\
\hline $\begin{array}{l}\text { A. chroococcum }+ \\
\text { A. lipoferum }\end{array}$ & & + yield,+ protein content & Sánchez-López et al., 2019 \\
\hline A. brasilense & Potato (Solanum tuberosum L.) & + survival rate, + seedling quality & $\begin{array}{l}\text { Kargapolova et al., 2020; } \\
\text { Tkachenko et al., } 2015\end{array}$ \\
\hline A. lipoferum & & + disease protection & Mehmood et al., 2021 \\
\hline \multirow[t]{4}{*}{ Azospirillum sp. } & & + growth, + IAA content & Naqqash et al., 2016 \\
\hline & Sugar beet (Beta vulgaris L.) & + yield,+ root quality & Amin et al., 2013 \\
\hline & Yam (Dioscorea sp.) & + yield,+ root quality & $\begin{array}{l}\text { Suja et al., 2012; } \\
\text { Suja \& Sreekumar, } 2014\end{array}$ \\
\hline & Radish (Raphanus sativus L.) & - growth, - root quality, - yield & Pathak et al., 2017 \\
\hline
\end{tabular}

A. amazonenses effectively increased the diameter of the roots of cassava micropropagated seedlings when co-inoculation with Glomus clarum (Lopes et al., 2019).

Regarding the quality of starch, the inoculation of plants with plant growth-promoting rhizobacteria, including Azospirillum, did not have a significant effect (Hernández-Fernández et al., 2016). In contrast, evaluating the effect of inoculating cassava plants with a product containing A. brasilense, Sharara \& El-Aal (2016) observed increases in the vitamin $C$ levels in the roots without affecting the development and yield. Result different from that obtained by Hridya \& Byju (2014), who verified the positive effect of inoculating plants with Azospirillum on root yield, in addition to increasing nutrient absorption and protection against infection caused by Phytophthora palmivora.

The use of biological products containing Azospirillum also influenced the production and quality of sweet potatoes (Ipomoea batatas [L.] Lam.), allowing lower doses of chemical fertilizers to be spent on obtaining products with quality similar to conventional cultivation (Nedunchezhiyan et al., 2010). Similar results were observed in a study in which A. lipoferum provided yield gains and protein content in sweet potato roots, even under conditions of reduced use of nitrogen fertilizer (Pérez-Pazos \& SánchezLópez, 2018; Sánchez-López et al., 2019). The authors related, among other factors already mentioned, to the improvement of soil quality in the rhizosphere region of this species, allowing greater absorption of nutrients (Subair, 2015; Si et al., 2018).

The action of the species A.brasilense and A.lipoferum also allowed them to be classified as promoters of development in different conditions in the Colombian Caribbean region (Pérez-Pazos \& Sánchez-López, 2017). Both species reduced acetylene concentrations, indicating the nitrogen fixation capacity of this plant species, culminating in an increase in root structures responsible for soil exploration.

As observed for the tomato crop, for the potato crop (Solanum tuberosum L.), belonging to the same botanical family, there was also a high response to inoculation with bacteria of the genus Azospirillum. The inoculation of micropropagated plants confirmed this fact. There was an increase in the efficiency of clonal propagation, survival, and quality of the seedlings produced and their ex vitro development (Kargapolova et al., 2020). This beneficial effect observed during seedling production reflects greater vegetative growth and yield gains from tubers, as observed for different potato materials grown in the field (Tkachenko et al., 2015) and increasing the production of IAA and the accumulation of matter in plant tissues grown in a greenhouse (Naqqash et al., 2016). 
Also, for potato cultivation, it was verified that inoculation with $A$. lipoferum resulted in activation of the protection mechanisms of plants against Alternaria solani, one of the main diseases that affect the species. In this study, the authors found a significant decrease in symptoms in plants treated with the bacterium, relating the effect to the initial reaction of plants to inoculation, with the activation of enzymes responsible for the production of phenolic compounds linked to the immune system of plants. Also, it appears that A. lipoferum has a direct antagonistic action concerning Alternaria solani, which culminates in a decrease in infection by the pathogen and an increase in yield (Mehmood et al., 2021).

For other species of vegetables producing roots and tubers, it was found that the application of bacteria of the Azospirillum genus led to increased yield and quality of the harvested products, as in the case of sugar beet (Beta vulgaris L.) (Amin et al., 2013) and three species of yam (Dioscorea sp.) (Suja et al., 2012; Suja \& Sreekumar, 2014). In contrast, the presence of bacteria hindered the initial development, production, and quality of radish (Pathak et al., 2017), demonstrating the importance of obtaining specific data for each relationship between bacteria and cultivated species.

\section{CONCLUSIONS}

The use of bacteria of the genus Azospirillum has been widely debated and applied to modern agriculture. This fact meets the social demands regarding reducing environmentally negative practices, as in the case of the excessive use of inputs, such as mineral fertilizers and pesticides, to control diseases. This possibility of mitigating the effects of anthropic activity on the environment is given by the ability of bacteria to increase the effectiveness of using fertilizers and provide plants with self-protection against biotic and abiotic factors through a series of morphological, physiological, nutritional and molecular factors.

Despite the understanding of the mechanisms of action of bacteria and their contribution to the development of more environmentally efficient agriculture, its application to vegetable production, even though it is not a novelty in the scientific community, still lacks information, partly due to the great complexity generated by the number of species cultivated. The interactions between plants and microorganisms depend on several factors, not only on compatibility but also concerning the characteristics of the growing environment.

Expanding the network of knowledge about the implications of using the Azospirillum genus in vegetable production goes beyond enabling a better understanding of the interaction between species. This understanding directly influences one of the sectors with the greatest employment of family labor, responsible for maintaining a large part of the rural population worldwide. Thus, the development of studies that allow the correct use of a proven effective technology has the characteristics aimed at socio-economic and environmental benefits.

Future studies should seek to deepen the physiological issues involved in the association between bacteria and horticultural species, analyzing how and when these effects effectively improve cultivation conditions. There is also a need to develop field studies under commercial cultivation conditions, in which environmental control is less and, therefore, the true potential of using bacteria of the Azospirillum genus may be highlighted or discarded.

\section{Bibliography}

Abou El-Magd M.M., Zaki M.F. \& Abo Sedera S.A., 2014. Effect of bio-nitrogen as a partial alternative to mineralnitrogen fertilizer on growth, yield and head quality of broccoli (Brassica oleracea L. var. italica). World Appl. Sci. J., 31(5), 681-691, doi.org/10.5829/idosi. wasj.2014.31.05.14328

Aguirre-Medina J.F. \& Espinosa Moreno J.A., 2016. Growth and yield of Capsicum annиum L. inoculated with endomycorrhiza and rhizobacterias. Revista Mex. Cienc. Agrícolas, 7(7), 1539-1550.

Aguirre P.F. et al., 2018. Forage yield of coastcross-1 pastures inoculated with Azospirillum brasilense. Acta Sci. Anim. Sci., 40, e36392, doi.org/10.4025/ actascianimsci.v40i1.36392

Altamirano L., Ramos E., Iglesias-Osores S. \& CarreñoFarfan C., 2020. Potentialities of polyhydroxyalkanoate (PHA) producing bacteria isolated from Asparagus officinalis L., doi.org/10.1590/SciELOPreprints.646

Amin G.A., Badr E.A. \& Afifi M.H.M., 2013. Root yield and quality of sugar beet (Beta vulgaris L.) in response to biofertilizer and foliar application with micronutrients. World Appl. Sci. J., 27(11), 1385-1389, doi.org/10.5829/ idosi.wasj.2013.27.11.13732

Andrade F.M. et al., 2019. Beneficial effects of inoculation of growth-promoting bacteria in strawberry.Microbiol.Res., 223, 120-128, doi.org/10.1016/j.micres.2019.04.005

Aponte A. et al., 2017. Rhizobacteria Pseudomonas fluorescens and Azospirillum sp. association enhances growth of Lactuca sativa L. under tropical conditions. J. Cent. Eur. Agric., 18(2), 424-440, doi.org/ 10.5513/ JCEA01/18.2.1916

Baliah N.T., Muthulakshmi P. \& Rajalakshmi V., 2015. Effect of Azospirillum on the growth and biochemical characters of okra (Abelmoschus esculentus (L.) Moench.). Int. J. Adv. Res., 3(12), 1272-1280.

Baliah T.N. \& Muthulakshmi P., 2017. Effect of microbially enriched vermicompost on the growth and biochemical 
characteristics of Okra (Abelmoschus esculentus (L.) Moench). Adv. Plants Agric. Res., 6(5), 00228, doi. org/10.15406/apar.2017.06.00228

Barassi C.A. et al., 2006. Seed inoculation with Azospirillum mitigates $\mathrm{NaCl}$ effects on lettuce. Sci. Hortic., 109, 8-1, doi.org/10.1016/j.scienta.2006.02.025

Caradonia F. et al., 2020. Biostimulants and cherry rootstock increased tomato fruit yield and quality in sustainable farming systems. Ital. J. Agron., 15(2), 121-131, doi. org/10.4081/ija.2020.1553

Cassán F. \& Diaz-Zorita M., 2016. Azospirillum sp. in current agriculture: from the laboratory to the field. Soil Biol. Biochem., 103, 117-130, doi.org/10.1016/j. soilbio.2016.08.020

Cassán F. et al., 2020. Everything you must know about Azospirillum and its impact on agriculture and beyond. Biol. Fertil. Soils, 56, 461-479, doi.org/10.1007/s00374020-01463-y

Cortés-Jiménez D. et al., 2014. Microorganisms associated to tomato seedlings growing in saline culture act as osmoprotectant. Braz. J. Microbiol., 45(2), 613-620, doi. org/10.1590/S1517-83822014000200032

Darabi F., Hatami A. \& Zare M.J., 2014. Plant growth promoting rhizobacteria improved growth, yield and yield components of lentil (Lens culinaris Medic) under shading growing conditions. Int. J. Biosci., 4, 346-352, doi.org/10.12692/ijb/4.12.346-352

Dudás A. et al., 2017. Sporeforming bacillus bioeffectors for healthier fruit quality of tomato in pots and field. Appl. Ecol.Environ. Res., 15(4), 1399-1418, doi.org/10.15666/ aeer/1504_13991418

Ejaz S. et al., 2020. Effects of inoculation of root-associative Azospirillum and Agrobacterium strains on growth, yield and quality of pea (Pisum sativum L.) grown under different nitrogen and phosphorus regimes. Sci. Hortic., 270, 109401, doi.org/10.1016/j.scienta.2020.109401

Eldeen U.M.S., Ezzat A.S. \& El-Kadi S.M., 2015. Effect of intercropping practices of globe artichoke (Cynara scolymus L.) with garlic (Allium sativum L.), N-rates and biofertilizers on growth, productivity, land equivalent ratio and microbiological properties in globe artichoke rhizosphere. Egypt. J. Hortic., 42(1), 509-530, dx.doi. org/10.21608/ejoh.2015.1313

El-Esawi M.A., Al-Ghamdi A.A., Ali H.M. \& Alayafi A.A., 2019. Azospirillum lipoferum FK1 confers improved salt tolerance in chickpea (Cicer arietinum L.) by modulating osmolytes, antioxidant machinery and stress-related genes expression. Environ. Exp. Bot., 159, 55-65, doi. org/10.1016/j.envexpbot.2018.12.001

Elías J.M. et al., 2018. Role of ethylene and related gene expression in the interaction between strawberry plants and the plant growth-promoting bacterium Azospirillum brasilense. Plant Biol., 20(3), 490-496, doi.org/10.1111/ plb.12697

El Sayed H.E., Younis R.O.A. \& Al Othaimen H.S., 2015. Responses of changes in productivity, yield and fruit quality of cucumber (Cucumis sativus L.) plant under bio-and chemical nutrition. Eur. J. Acad. Essays, 2(7), 68-74.

Escalante F.M., Cortés-Jiménez D., Tapia-Reyes G. \& Suárez R., 2015. Immobilized microalgae and bacteria improve salt tolerance of tomato seedlings grown hydroponically. J. Appl. Phycol., 27(5), 1923-1933, doi. org/10.1007/s10811-015-0651-0

Esquivel-Cote R., Tsuzuki-Reyes G., Ramírez-Gama R.M. \& Huante P., 2017. Effect of inoculation with Azospirillum sp., and nitrogenous fertilization on the growth and production of tomato (Solanum lycopersicum Mill.). Agroproductividad, 10(7), 88-93.

Fasciglione G. et al., 2015. Azospirillum inoculation effects on growth, product quality and storage life of lettuce plants grown under salt stress. Sci. Hortic., 195(1), 154162, doi.org/10.1016/j.scienta.2015.09.015

Filipini L.D. et al., 2020. Application of Azospirillum on seeds and leaves, associated with Rhizobium inoculation, increases growth and yield of common bean. Arch. Microbiol., 203, 1033-1038, doi.org/10.1007/s00203020-02092-7

Fujita M. et al., 2017. Effects of colonization of a bacterial endophyte, Azospirillum sp. B510, on disease resistance in tomato. Biosci. Biotechnol. Biochem., 81(8), $1657-$ 1662, doi.org/10.1080/09168451.2017.1329621

Fukami J. et al., 2018. Co-inoculation of maize with Azospirillum brasilense and Rhizobium tropici as a strategy to mitigate salinity stress. Funct. Plant Biol., 45(3), 328-339, doi.org/10.1071/FP17167

Guerrero-Molina M.F. et al., 2014. Physiological, structural and molecular traits activated in strawberry plants after inoculation with the plant growth-promoting bacterium Azospirillum brasilense REC3. Plant Biol., 17(3), 766773, doi.org/10.1111/plb.12270

Hernández-Fernández N. et al., 2016. Impact of organic fertilization on physicochemical and functional properties of cassava starch. Starch, 68(5-6), 549-557, doi.org/10.1002/star.201500257

Hernández J.L.G. et al., 2018. Growth and oil yield parameters of the Capsicum annuum var aviculare associated to the beneficial bacterium Bacillus amyloliquefaciens and Azospirillum halopraeferens under field conditions. Biotecnia, 20(2), 59-64, doi. org/10.18633/biotecnia.v20i2.599

Hridya A.C. \& Byju G., 2014. Effect of chemical fertilizers and microbial inoculations on soil properties in cassava (Manihot esculenta) growing Vertisols of Tamil Nadu. Indian J. Agric. Sci., 84(7), 860-866, doi.org/10.1080/03 650340.2012 .702896

Idris E.E., Iglesias D.J., Talon M. \& Borriss R., 2007. Tryptophan-dependent production of indole-3-acetic acid (IAA) affects level of plant growth promotion by Bacillus amyloliquefaciens FZB42. Mol. Plant-Microbe Interact., 20(6), 619-626, doi.org/ 10.1094/MPMI-20-60619 
Kargapolova K.Y. et al., 2020. Effectiveness of inoculation of in vitro-grown potato microplants with rhizosphere bacteria of the genus Azospirillum. Plant Cell Tissue Organ Cult. (PCTOC), 141, 351-359, doi.org/10.1007/ s11240-020-01791-9

Kholdi A., Sedaghathoor S. \& Poursafarali E., 2015. Effect of nitroxin and humic acid on yield and yield components of faba bean. J. Agric. Sci., 60(3), 361-367, doi.org/10.2298/JAS1503361K

Kloepper J.W. \& Schroth M.N., 1978. Plant growthpromoting rhizobacteria in radish. In: Proceedings of the $4^{\text {th }}$ International conference of plant pathogenic bacteria, August 27-September 2, 1978, Angers, France, 879-882.

Komy M.H. et al., 2020. A mixture of Azotobacter, Azospirillum, and Klebsiella strains improves root-rot disease complex management and promotes growth in sunflowers in calcareous soil. Eur. J. Plant Pathol., 156(3), 713-726, doi.org/10.1007/s10658-019-01921-w

Kumar M. et al., 2018. Influence of bio-fertilizers application on growth, yield and quality attributes of cucumber (Cucumis sativus L.): a review. Plant Arch., 18(2), 2329-2334.

Kumar S. et al., 2019. Substitution of mineral fertilizers with biofertilizer: an alternate to improve the growth, yield and functional biochemical properties of strawberry (Fragaria $\times$ Ananassa Duch.) cv. Camarosa. J. Plant Nutr., 42(15), 1818-1837, doi.org/10.1080/01904167.2 019.1643363

Lade S.B. et al., 2018. Host-specific proteomic and growth analysis of maize and tomato seedlings inoculated with Azospirillum brasilense Sp7. Plant Physiol. Biochem., 129, 381-393, doi.org/10.1016/j.plaphy.2018.06.024

Lai W.A., Rekha P.D., Arun A.B. \& Young C.C., 2008. Effect of mineral fertilizer, pig manure, and Azospirillum rugosum on growth and nutrient contents of Lactuca sativa L. Biol. Fertil. Soils, 45(2), 155-164, doi.org/ 10.1007/s00374-008-0313-3

Leite M.C.D.B.S. et al., 2018. Bioprospection and genetic diversity of endophytic bacteria associated with cassava plant. Rev. Caatinga, 31(2), 315-325, doi. org/10.1590/1983-21252018v31n207rc

Leite R. da C. et al., 2019. Productivity increase, reduction of nitrogen fertiliser use and drought-stress mitigation by inoculation of Marandu grass (Urochloa brizantha) with Azospirillum brasilense. Crop Pasture Sci., 70(1), 61, doi.org/10.1071/cp18105

Leveau J.H. \& Lindow S.E., 2005. Utilization of the plant hormone indole-3-acetic acid for growth by Pseudomonas putida strain 1290. Appl. Environ. Microbiol., 71(5), 2365-2371, doi.org/ 10.1128/AEM.71.5.2365-2371.2005

Lima A.A. et al., 2017. Eficiência da inoculação de Azospirillum brasilense associado com enraizador no crescimento e na produção de alface. Rev. Verde Agroecol. Desenvolv. Sustent., 12(2), 233-240, doi. org/10.18378/rvads.v12i2.4300
Lima N.D.S.A., Vogel G.F. \& Fey R., 2018. Rates of application of Azospirillum brasilense in tomato crop. Rev. Agric. Neotrop., 5(4), 81-87, doi.org/10.32404/rean. v5i4.3142

Lopes E.A.P. et al., 2019. Co-inoculation of growth promoting bacteria and Glomus clarum in micropropagated cassava plants. Rev. Caatinga, 32(1), 152-166, doi.org/10.1590/1983-21252019v32n116rc

López N.I., Ruiz J.A. \& Méndez B.S., 1998. Survival of poly-3-hydroxybutyrate-producing bacteria in soil microcosms. World J. Microbiol. Biotechnol., 14(5), 681-684, doi.org/10.1023/A:1008857420434

Mangmang J.S.,Deaker R.\& Rogers G.,2015a.Azospirillum brasilense enhances recycling of fish effluent to support growth of tomato seedlings. Horticulturae, 1(1), 14-26, doi.org/10.3390/horticulturae1010014

Mangmang J.S., Deaker R. \& Rogers G., 2015b. Early seedling growth response of lettuce, tomato and cucumber to Azospirillum brasilense inoculated by soaking and drenching. Hortic. Sci., 42, 37-46, doi. org/10.17221/159/2014-HORTSCI

Mangmang J.S., Deaker R. \& Rogers G., 2016. Response of cucumber seedlings fertilized with fish effluent to Azospirillum brasilense. Int. J. Vegetable Sci., 22(2), 129-140, doi.org/10.1080/19315260.2014.967433

Marastoni L. et al., 2019. Role of Azospirillum brasilense in triggering different $\mathrm{Fe}$ chelate reductase enzymes in cucumber plants subjected to both nutrient deficiency and toxicity. Plant Physiol. Biochem., 136, 118-126, doi. org/10.1016/j.plaphy.2019.01.013

Mehmood T., Li G., Anjum T. \& Akram W., 2021. Azospirillum lipoferum strain AL-3 reduces early blight disease of potato and enhance yield. Crop Prot., 139, 105349, doi.org/10.1016/j.cropro.2020.105349

Montenegro-Gómez S.P., Gómez-Posada S. \& BarreraBerdugo S.E., 2017. Efecto de la gallinaza sobre Azotobacter sp., Azospirillum sp. y hongos micorrízicos arbusculares en un cultivo de cebolla (Allium fistulosum). Entramado, 13(2), 250-257, doi.org/10.18041/ entramado. $2017 \mathrm{v} 13 \mathrm{n} 2.26232$

Naqqash T. et al., 2016. Differential response of potato toward inoculation with taxonomically diverse plant growth promoting rhizobacteria. Frontiers Plant Sci., 7, 144, doi.org/10.3389/fpls.2016.00144

Nedunchezhiyan M., Byju G. \& Dash S.N., 2010. Effects of organic production of orange fleshed sweet potato (Ipomoea batatas L.) on root yield, quality and soil biological health. Int. Res. J. Plant Sci., 1(6), 136-143.

Pathak M. et al., 2017. Effect of source of nutrient on growth, yield and quality of radish (Raphanus sativus L.) in radish-coriander cropping sequence. Pharma Innov. J., 6(12), 496-499.

Paz R.B. de O. et al., 2020. Desempenho agronômico de cultivares de mandioca de mesa em ambiente do cerrado. Colloq. Agrariae, 16(3), 37-47, doi.org/10.5747/ ca.2020.v16.n3 .a370 
Pereg L., de-Bashan L.E. \& Bashan Y., 2016. Assessment of affinity and specificity of Azospirillum for plants. Plant Soil, 399(1-2), 389-414, doi.org/10.1007/s11104-0152778-9

Pérez-Pazos J.V. \& Sánchez-López D.B., 2017. Caracterización y efecto de Azotobacter, Azospirillum y Pseudomonas asociadas a Ipomoea batatas del Caribe Colombiano. Rev. Colomb. Biotecnol., 19(2), 35-46, doi. org/10.15446/rev.colomb.biote.v19n2.69471

Pérez-Pazos J.V. \& Sánchez-López D.B., 2018. Influence of plant growth promoting bacteria in seed yields of superelite sweet potato (Ipomoea batatas Lam) in the field. Biotecnol. Apl., 35(2), 1501-1503.

Pérez-Rodriguez M.M. et al., 2020. Pseudomonas fluorescens and Azospirillum brasilense increase yield and fruit quality of tomato under field conditions. J. Soil Sci. Plant Nutr., 20, 1614-1624, doi.org/10.1007/ s42729-020-00233-x

Reddy G.C. \& Goyal R.K., 2021. Growth, yield and quality of strawberry as affected by fertilizer $\mathrm{N}$ rate and biofertilizers inoculation under greenhouse conditions. J. Plant Nutr., 44(1), 1-13, doi.org/10.1080/01904167. 2020.1806301

Reyes-Ramirez A. et al., 2014. Effectiveness of microbial inoculants on growth and productivity of habanero pepper (Capsicum chinense Jacq.). Agrociencia, 48(3), 285-294.

Romagna I.S., Junges E., Karsburg P.A. \& Pinto S.Q., 2019. Bioestimulantes em sementes de olerícolas submetidos a testes de germinação e vigor. Sci. Plena, 10(10), 100201. doi.org/10.14808/sci.plena.2019.100201

Romero A.M., Vega D. \& Correa O.S., 2014. Azospirillum brasilense mitigates water stress imposed by a vascular disease by increasing xylem vessel area and stem hydraulic conductivity in tomato. Appl. Soil Ecol., 82, 38-43, doi.org/10.1016/j.apsoil.2014.05.010

Romero W.C. et al., 2016. Producción de plántulas de hortalizas con Azospirillum sp. y aspersión foliar de miel de abeja. Rev. Mexicana Cienc. Agríc., 7(1), 59-70, doi. org/10.29312/remexca.v7i1.370

Sahu P.K., Gupta A., Sharma L. \& Bakade R., 2017. Mechanisms of Azospirillum in plant growth promotion. Agric. Vet. Sci., 4, 338-343, doi.org/10.21276/ sjavs.2017.4.9.3

Salazar S.M. et al., 2012. Fruit yield of strawberry plants inoculated with Azospirillum brasilense RLC1 and REC3 under field conditions. Rev. Agron. Noroeste Argent., 32(1-2), 63-66.

Sánchez-López D.B. et al., 2019. Azotobacter chroococcum y Azospirillum lipoferum como bioestimulantes en cultivo de Ipomoea batatas Lam. Agron. Mesoam., 30(2), 563-576.
Sharara M.S. \& Abd El-Aal H.A., 2016. Effect of some biofertilizers on growth, productivity, chemical composition and processing of cassava tubers. Alexandria J. Agric. Sci., 61(6).

Sharma I.J., Samnotra R.K. \& Vijay K., 2014. Influence of biofertilizer application methods and inorganic fertilizers on growth, seed yield and economics cost of okra [Abelmoschus esculentus (L.) Moench] under sub-tropical irrigated area of Jammu. Int. J. Agric. Sci., 10(1), 322-328.

Si C. et al., 2018. Influence of two nitrogen forms on hormone metabolism in potential storage roots and storage root number of sweet potato. Crop Sci., 58, 1-11, doi.org/10.2135/cropsci2018.01.0067

Silva E.R. et al., 2019. Can co-inoculation of Bradyrhizobium and Azospirillum alleviate adverse effects of drought stress on soybean (Glycine max L. Merrill.)? Arch. Microbiol., 201(3), 325-335, doi.org/10.1007/s00203018-01617-5

Subair H., 2015. Isolation and screening bacterial exopolysaccharide (EPS) from potato rhizosphere in highland and the potential as a producer indole acetic acid (IAA). Proc. Food Sci., 3, 74-81, doi.org/10.1016/j. profoo.2015.01.007

Suja G., Sreekumar J., John K.S. \& Sundaresan S., 2012. Organic production of tuberous vegetables: agronomic, nutritional and economic benefits. J. Root Crops, 38(2), 135-141.

Suja G. \& Sreekumar J., 2014. Implications of organic management on yield, tuber quality and soil health in yams in the humid tropics. Int. J. Plant Prod., 8(3), 291310 .

Tkachenko O.V. et al., 2015. Improved potato microclonal reproduction with the plant growth-promoting rhizobacteria Azospirillum. Agron. Sustain. Dev., 35(3), 1167-1174, doi.org/10.1007/s13593-015-0304-3

Vendruscolo E.P. et al., 2019. Planting method, nitrogen fertilization and inoculation for diazotrophic bacteria for Cantaloupe melon plants. Rev. Colomb. Cienc. Hortíc., 13(1), 18-25, doi.org/10.17584/rcch.2019v13i1 .9720

Vendruscolo E.P. et al., 2020. Do planting methods and nitrogen management interfere with the economic viability of the melon crop? Comun. Sci., 11, e3127, doi. org/10.14295/cs.v11i0.3127

Zarei D.et al.,2015.Effects of different nutritional systems on seed germination and early seedling growth in medicinal pumpkin (Cucurbita pepo L.). Cercet. Agron. Moldova, 48(4), 51-60, doi.org/10.1515/cerce-2015-0052 